\title{
Product Prices, Service Quality, Promotion Affect Decisions on Purchasing Motorcycle Parts
}

\author{
Purnama Yanti Purba ${ }^{1}$, Andi $^{2}$, Tania Pratiwi ${ }^{3}$, Jhas Jensen ${ }^{4}$, Ade Irwansyah ${ }^{5}$
}

1,2,3,4,5 Universitas Prima Indonesia, Medan, Indonesia

\section{A R T I C L E IN F O}

Article history:

Received 18 May 2020

Received in revised form

5 June 2020

Accepted 18 July 2020

Available online 29 August

2020

Keywords:

Harga, Kualitas Pelayanan,

Promosi, keputusan

pembelian

\section{A B S T R A C T}

This research was motivated by the high number of customer complaints in 2019, higher prices compared to competitors, and the lack of sales targets in the last few months. This research aimed to analyze the effect of price, service quality, and promotion on motorcycle spare parts purchasing decisions. This type of research was a quantitative descriptive study. The population in this research were 1890 customers who purchased genuine Honda spare parts at PT Indako Trading Coy. Sampling using simple random sampling technique, in order to obtain a sample of 237 people. Data collection using a questionnaire method. The data were analyzed using multiple linear regression tests. The results of the research and data analysis showed that partially the product price, service quality, and promotion have a significant influence on the decision to purchase motorcycle spare parts. Hypothesis testing shows that Fcount> Ftable (75.204> 2.64) with a significance of $0.000<0.05$. Based on this, it can be concluded that price, service quality and promotion have a positive and significant effect simultaneously on the decision to purchase motorcycle parts. 


\section{Introduction}

The current globalization and modernization are accompanied by the growth and development of the people's economy. The growth of the community's economy will have an impact on the increasing needs of the community. To fulfill their needs, the public will take pleasure in getting satisfaction with the products or services that are being traded on the market (Santosa, 2019; Sunarto, 2015). One of the production sectors that have increased along with economic growth and development is the automotive sector.

The development of automotive in Indonesia has made significant progress, especially in twowheeled vehicles. This is in line with various innovations in motorbikes that have used sophisticated technology. The Indonesian Motorcycle Industry Association recorded motorcycle sales in 2019 reaching 6,487,430 units, with details of Honda contributing sales of 4,910,688 units or 75,69\%, Yamaha with sales of $1,434,217$ units or $22,1 \%$, Suzuki with total sales of 71,861 units or $1,1 \%$, Kawasaki with sales of 69,766 units or $1.08 \%$, TVS with sales of 898 or $0,01 \%$. This makes Honda the most popular motorcycle brand in Indonesia (Rustam, 2019).

The high number of sales of Honda motorcycles provides many opportunities that can be achieved by all levels of society, one of which is economic actors. Economic players will see these high sales figures as an opportunity. And one of the opportunities that can be entered is in the spare parts section (Rustam, 2019). Spare parts are parts or spare parts that make up several motorcycle components from the engine frame to the motorcycle body. Therefore, the presence of a company that sells special Honda motorcycle parts is definitely needed by the public, such as PT Indako Trading Coy.

PT Indako Trading Coy is a company engaged in the automotive sector. When PT Astra Internasional was appointed as the sole distributor for Honda in Indonesia in 1971, PT Astra International appointed PT Indako Trading Coy as the main dealer for Honda motorcycles for North Sumatra. Also as a main dealer of Honda spare parts (Honda Genuine Part) for North Sumatra and Aceh.

Table 1. Recapitulation of Honda Motorcycle Parts Sales Data

\begin{tabular}{clcc}
\hline Month & Total Sales & Sales Target & \% \\
\hline January & Rp236.993.169 & Rp229.500.000 & 103 \\
February & Rp209.367.213 & Rp233.550.000 & 90 \\
March & Rp224.020.756 & Rp235.170.000 & 95 \\
April & Rp223.090.682 & Rp224.640.000 & 99 \\
May & Rp286.065.267 & Rp235.440.000 202.500 .000 & 122 \\
June & Rp208.177.211 & Rp243.000.000 & 103 \\
July & Rp276.034.466 & Rp234.360.000 & 114 \\
August & Rp270.440.102 & Rp221.400.000 & 115 \\
September & Rp270.649.711 & Rp216.270.000 & 122 \\
October & Rp271.340.440 & Rp216.270.000 & 125 \\
November & Rp278.219.530 & Rp207.900.000 & 129 \\
December & Rp288.619.840 & & 139 \\
\hline
\end{tabular}

Source: PT Indako Trading Coy

Table 1 show that the realization of spare parts sales in February, March, April did not reach the sales target set by the company. This is allegedly due to reduced consumer decisions to purchase spare parts. Several factors can influence consumer decisions, one of which is price. Reduced consumer interest in buying genuine Honda parts because the prices are relatively expensive compared to non-genuine Honda motorcycle parts.

In addition to price, the services provided by employees in serving consumers are of unfriendly value. Employees often do not serve consumers well, there are even some employees who do not care about consumers who come to purchase genuine Honda spare parts, besides that the way employees handle consumer complaints about spare parts is not good value, and the facilities provided by the company to consumers are considered as not maximal. This is considered to be able to influence consumer decisions in purchasing genuine Honda spare parts. Service quality is seen as one of the components that need to be realized by the company because it has the influence to bring in new customers and can reduce the possibility of old customers to move to another company (Cronin. \& Taylor, 
1992; Peter \& Olson, 2013). With so many competitors appearing in the market, there will also be more choices for consumers to make their choices. This makes it even harder for the company to retain old customers. Therefore, the quality of service that has been carried out by the company must be maximally improved in order to attract new consumers and to protect old customers.

The next problem that occurs in consumer decisions is related to promotion. Promotion is one of the factors that can influence consumer interest in making purchases. Promotions are usually in the form of attractive promos made by companies, can be in the form of discounts given, or activities carried out by companies with the aim of attracting consumer attention. Sales promotion must be in the form of building good relationships between the company and consumers in order to create loyal customers to the company, and not just creating temporary short-term sales volumes, sales promotions must strengthen product positions and build long-term relationships with consumers. Often the promotions that are carried out are less effective in attracting consumers' attention to purchase genuine Honda parts, this can have an impact on the sales of genuine Honda parts so that it will be more difficult for the company to achieve the expected target.

Previous research conducted by (Petricia \& Syahputra, 2015) stated that prices, service quality, and promotions have a positive influence on purchasing decisions. Customers really want friendly service quality, supported by affordable product prices and attractive promotions about products. In line with this statement, research conducted by (Rustam, 2019) found that promotion has a positive influence on customer decisions in making purchases. Furthermore, research conducted by (Kurniawan, 2016; Margaretha, 2012) stated that price and service quality are factors that affect purchasing decisions.

Based on the background presentation and the results of previous research, this study aims to analyze the effect of price, service quality, and promotion on motorcycle spare parts purchasing decisions at PT Indako Trading Coy.

\section{Methods}

This research used a quantitative research approach. Quantitative research can be interpreted as a research method based on the philosophy of positivism, used to examine specific populations or samples, sampling techniques in general, carried out randomly, data collection used research instruments, quantitative / statistical data analysis in order to test the hypothesis has been established (Sugiyono, 2014). This research was conducted at PT Indako Trading Coy. Located in the city of Medan, precisely located at Jl. Sisingamangaraja No.362, Siti Rejo I, Kec. Medan Kota, North Sumatra 20144. Research time during January 2019 to December 2020. The research framework which contains the relationship between the dependent variable and the independent variable in this study is presented in Figure 1.

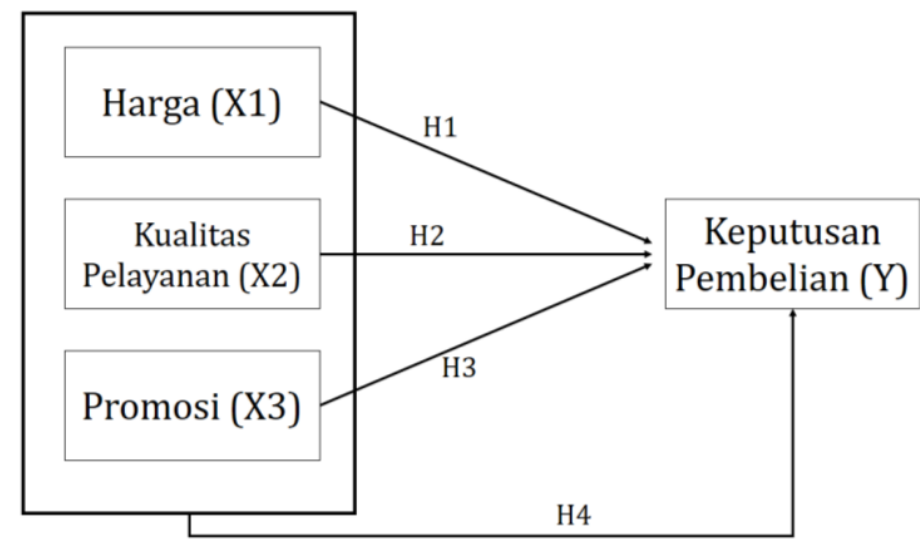

Figure 1. Research Design

The population in this study was 1890 customers of PT Indako Trading Coy who purchased genuine Honda spare parts in January-December 2019. Determination of the sample was using simple random sampling technique. Based on the sampling technique, 237 sample members were obtained.

Collecting data in this research was using an instrument in the form of a questionnaire. The total of all questionnaire questions is 42 questions consisting of 8 questions for price variables, 10 questions for service quality variables, 10 questions for promotion variables, and 14 questions for purchasing decision variables. A total of 237 respondents participated in filling out this questionnaire. Questionnaires containing questions regarding price, service quality, promotion, and decision to purchase Honda 
motorcycle spare parts at PT Indako Trading Coy were then distributed so that they could be filled in by respondents.

Price has several research indicators which include price affordability, price according to ability or price competitiveness, price compatibility with product quality, price compatibility with benefits (Kotler \& Amstrong, 2012). Service quality has several research indicators which include reliability, responsiveness, assurance, empathy, physical evidence (tangibles) (Tjiptono, 2015). Promotion has several research indicators which include, advertising, sales promotion, public relation, personal selling, direct marketing (Abdurrahman, 2015). The purchase decision has several research indicators, namely: a decision about the type of product, a decision about the shape of the product, a decision about the brand, a decision about the seller, a decision about the number of products, a decision about the time of purchase, a decision about how to pay (Alma, 2018).

The data size scale used in this study is the Likert scale, which is the range of 1 - 5 scores given, namely SS = Strongly agree (5), S = Agree (4), N = Neutral (3), TS = Disagree (2) ), STS = Very Not (1). Data analysis was using multiple linear regression analysis techniques. Multiple linear regression analysis technique is used to determine the relationship between the dependent and independent variables simultaneously. Calculation and processing of primary and secondary data uses the help of the SPSS program.

\section{Results and Discussions}

\section{Results}

Respondent Characteristics

Based on the results of distributing questionnaires to the research sample of 237 people, data on the characteristics of the respondents were obtained. The characteristics of the respondents were viewed from three aspects, namely gender, age and occupation. Recapitulation of findings regarding the characteristics of respondents can be seen in Table 2 .

Tabel 2. Respondent Characteristics

\begin{tabular}{|c|c|c|}
\hline \multirow[t]{2}{*}{ Respondent Characteristics } & Total (person) & Percentage (\%) \\
\hline & \multicolumn{2}{|c|}{ Gender } \\
\hline a. Male & 142 & 60 \\
\hline b. Female & 95 & 40 \\
\hline Total & 237 & 100 \\
\hline \multicolumn{3}{|c|}{ Age } \\
\hline a. $17-25$ years old & 121 & 51 \\
\hline b. $25-35$ years old & 86 & 36 \\
\hline c. $>35$ years old & 30 & 13 \\
\hline Total & 237 & 100 \\
\hline \multicolumn{3}{|c|}{ Job } \\
\hline a. General employees & 105 & 44 \\
\hline b. College student & 62 & 26 \\
\hline c. Housewife & 27 & 11 \\
\hline d. entrepreneur & 29 & 12 \\
\hline e. Does not work & 14 & 6 \\
\hline Total & 237 & 100 \\
\hline
\end{tabular}

The data above shows that male customers are the most dominant, namely as many as 142 people because most of the men do daily activities outside the home using motorbikes such as working. The most dominant customers aged 17-25 years, as many as 121 people, this is because young people use more motorbikes for daily activities such as college, touring. Then, customers who work as private employees are the most dominant, namely as many as 105 people because they carry out maintenance and replacement of damaged parts so that Honda motorbikes can be used comfortably in carrying out daily activities such as work.

\section{Descriptive Analysis Results}

In addition to obtaining data on the characteristics of respondents, other data obtained are data on prices, service quality, promotions, and purchasing decisions. The results of descriptive analysis of these data are presented in Table 3. 
Table 3. Descriptive Statistical Analysis Results

\begin{tabular}{lccccc}
\hline \multicolumn{1}{c}{ Variable } & N & Min & Max & Mean & Std. Deviation \\
\hline Price & 237 & 23 & 40 & 34,57 & 2,446 \\
Service quality & 237 & 35 & 46 & 41,66 & 2,208 \\
Promotion & 237 & 34 & 48 & 42,37 & 2,316 \\
Buying decision & 237 & 49 & 67 & 58,86 & 3,094 \\
Valid N (listwise) & 237 & & & & \\
\hline
\end{tabular}

The data shows the mean of the price variable (X1) which is 34.57 with a standard deviation of 2.446 , a minimum value of 23 and a maximum value of 40 .The mean of the service quality variable (X2) is 2.208 with a standard deviation of 2.208 , a minimum value of 35 , and a maximum value of 46 . The mean of the promotional variable $(\mathrm{x} 3)$ is 42.37 with a standard deviation of 2.316 , a minimum value of 34 , and a maximum value of 48 . The mean of the purchasing decision variable (Y) is 58.86 with a standard deviation of 3.094, a minimum value of 49 , and a maximum value of 67 .

\section{Normality Test Results}

The normality test is useful for testing regression models, confounding variables or residuals that have a normal distribution. The results of the normality test are presented in Figure 2.

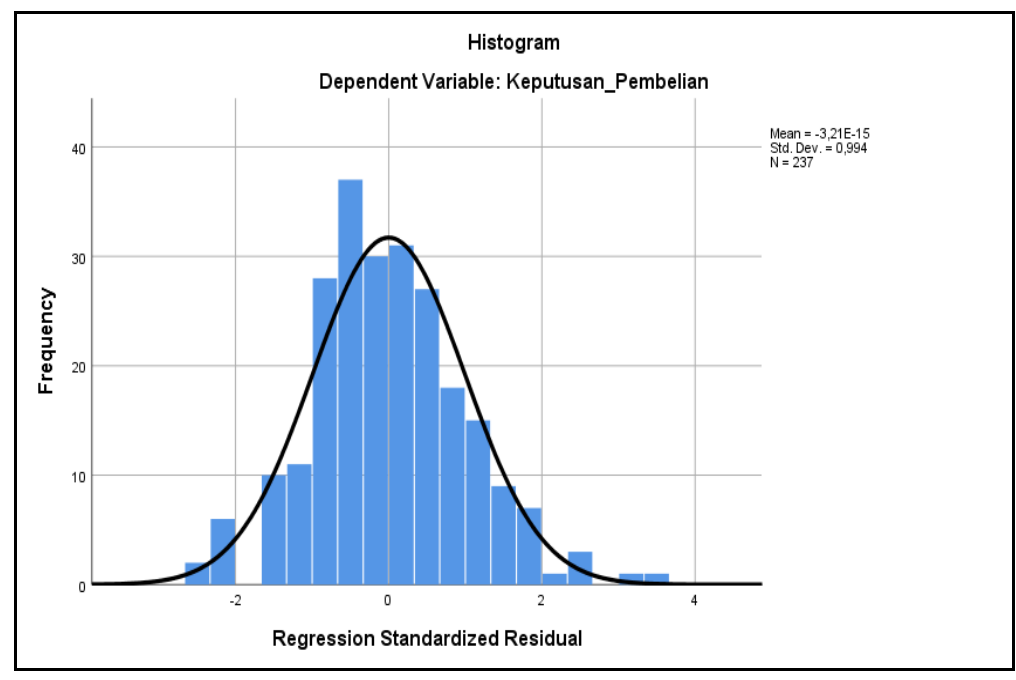

Figure 2. Histogram

From the histogram graph in Figure 2 above, the curve shows the shape of a bell and has an almost equal slope. Based on this, it can be interpreted that the analyzed data is normally distributed.

\section{Multicollinearity Test Results}

Multicollinearity test aims to determine whether there is a relationship between several independent variables in the regression. The multicollinearity test results are presented in Table 4 .

Table 4. Multicollinearity Test Results

\begin{tabular}{lccc}
\hline & Variable & Tolerance & VIF \\
\hline Price & .988 & 1.012 \\
Service quality & .989 & 1.011 \\
Promotion & .999 & 1.001 \\
\hline
\end{tabular}

From the table above, VIF $<10$ and tolerance $>0.1$, indicates that there is no multicollinearity and no problems. It is concluded that this study does not occur multicollinearity or is free from multicollinearity problems. 


\section{Heteroscedasticity Test Results}

The heteroscedasticity test aimed to test whether in the regression model there is an inequality of variance from the residuals of one observation to another. The results of the heteroscedasticity test are presented in Table 5.

Tablel 5. Heteroscedasticity Test Results

\begin{tabular}{lrrrrr}
\hline \multirow{2}{*}{ Variable } & \multicolumn{2}{c}{ Unstandarized Coefficients } & \multicolumn{3}{c}{ Standarized Coefficients } \\
\cline { 2 - 6 } & \multicolumn{1}{c}{ B } & Std. Error & B & \multicolumn{1}{c}{ t } & Sig \\
\hline Price & -.058 & .041 & -.093 & -1.425 & .155 \\
Service quality & -.040 & .041 & -.063 & .966 & .335 \\
Promotion & -.028 & .040 & -.045 & -.698 & .486 \\
Constant & 6.573 & 2.877 & 0 & 2.285 & .023 \\
\hline
\end{tabular}

Based on Table 5, it can be concluded that the data are normally distributed and do not experience heteroscedasticity problems. This can be seen from the value of Sig> 0.05 , so it can be said that this research is free from heteroscedasticity problems.

\section{Multiple Linear Regression Test Results}

Multiple linear regressions serve to test the effect of 2 or more independent variables with 1 dependent variable. The results of multiple linear regression tests can be seen in Table 6 .

Table 6. Multiple Linear Regression Test Results

\begin{tabular}{lcc}
\hline & \multirow{2}{*}{ Variable } & \multicolumn{2}{c}{ Unstandarized Coefficients } \\
\cline { 2 - 3 } & B & Std. Error \\
\hline Constant & -9.085 & 4.555 \\
Price & .443 & .065 \\
Service quality & .615 & .065 \\
Promotion & .633 & .063 \\
\hline
\end{tabular}
as follows.

Based on Table 6, the unstandardized coefficients obtained multiple linear regression equations

$$
Y=-9.085+0,443 X_{1}+0,615 X_{2}+0,633 X_{3}+e
$$

Information:

Y: Purchase Decision

X1: Price

X2: Qulity

X3: Promotion

e: Term of error or error clearance rate

\section{Hypothesis Test Results}

The t-test functions to show how much influence one variable has individually or independently in explaining the variation in the dependent variable. The t-test results can be seen in Table 7.

Table 7. t-test results

\begin{tabular}{lrrrrr}
\hline \multirow{2}{*}{ Variable } & \multicolumn{3}{c}{ Unstandarized Coefficients } & \multicolumn{3}{c}{ Standarized Coefficients } \\
\cline { 2 - 6 } Constant & \multicolumn{1}{c}{ B } & Std. Error & B & \multicolumn{1}{c}{ t } & \multicolumn{1}{c}{ Sig } \\
Price & -9.085 & 4.555 & & -1.994 & .047 \\
Service quality & .443 & .065 & .321 & 6.861 & .000 \\
Promotion & .615 & .065 & .440 & 9.399 & .000 \\
& .633 & .063 & .470 & 10.068 & .000 \\
\hline
\end{tabular}




\section{The Effect of Product Prices on Purchasing Decisions}

Based on Table 7, it is known that Sig. Price $0,000<0.05$ and tcount $>$ ttable $(6,861>1,652)$ so it can be concluded that the price has a significant influence on the decision to purchase Honda motorcycle parts at PT Indako Trading Coy.

\section{The Effect of Service Quality on Purchasing Decisions}

Based on Table 7, it is known that Sig. Service Quality $0,000<0.05$ and tcount $>$ ttable $(9,399>$ $1,652)$ so it can be concluded that Service Quality has a significant influence on the decision to purchase Honda motorcycle parts at PT Indako Trading Coy.

\section{Effect of Promotion on Purchasing Decisions}

Based on Table 7, it is known that Sig. Promotion $0.000<0.05$ and tcount $>$ ttable $(10.068>1.652)$ so it can be concluded that Promotion has a significant influence on the decision to purchase Honda motorcycle spare parts at PT Indako Trading Coy.

Furthermore, the f-test is useful for knowing simultaneously the independent variable has a significant or no effect on the dependent variable. The results of the f-test are presented in Table 6.

Table 8. F-test results

\begin{tabular}{lccccc}
\hline \multicolumn{1}{c}{ Model } & $\begin{array}{c}\text { Sum of } \\
\text { Squares }\end{array}$ & Df & Mean Square & F & Sig. \\
\hline Regression & 1115.010 & 3 & 371.670 & 75.204 & .000 \\
\hline Residual & 1151.521 & 233 & 4.942 & & \\
\hline Total & 2266.532 & 236 & & & \\
\hline
\end{tabular}

Based on Table 8, the test results obtained Fcount 75.204 with a significance level of 0.000 . Meanwhile, Ftable with a confidence level of $95 \%(\alpha=0.05)$, namely 2.64, is caused by Fcount> Ftable or $75.204>2.64$ with a significant $0.000<0.05$, then $\mathrm{Ha}$ is accepted and $\mathrm{HO}$ is rejected. This proves that the price, service quality and promotion have a significant and simultaneous influence on the decision to purchase Honda motorcycle parts at PT Indako Trading Coy.

\section{Discussion}

\section{Effect of Product Prices on Purchasing Decisions}

Based on the research results, product prices have a significant influence on the decision to purchase Honda motorcycle parts at PT Indako Trading Coy. This is in line with research conducted by (Carlos Alberto et al., 2020; Consuegra, Martin et al., 2007; Kukar-Kinney et al., 2012; Kurniawan, 2016) which stated that product prices greatly determine consumer decisions in making purchases. This statement is also supported by (Petricia \& Syahputra, 2015) which stated that the higher a person's perception of a reasonable or affordable price, the positive impact on purchasing decisions. In this case, the price has a positive influence on purchasing decisions because a reasonable price will be affordable and accepted by consumers, so as to increase the decision to make a purchase. The higher the price reasonableness, the higher the chance for consumers to make a purchase. Conversely, if the reasonableness of the price is getting lower, the chances of consumer purchasing decisions will be even lower.

\section{The Effect of Service Quality on Purchasing Decisions}

Based on the research results, service quality has a significant influence on the decision to purchase Honda motorcycle spare parts at PT Indako Trading Coy. These findings are in line with the results of research conducted by (Kurniawan, 2016; Petricia \& Syahputra, 2015) which stated that the better the quality of service provided, the higher the chance for consumers to make purchases. This statement is also supported by (Chang Li, 2013; Santosa, 2019) which stated that service quality has a significant impact on purchasing decisions and customer satisfaction. In this case, service quality has a significant effect on purchasing decisions because good service quality will result in a good level of satisfaction and comfort for individuals. Satisfaction and comfort will influence someone to make a purchase. The higher the quality of service, the higher the chances of consumers making a purchase. Conversely, the lower the quality of service, the lower the chance for consumers to make a purchase. 


\section{Effect of Promotion on Purchasing Decisions}

Based on the research results, promotion has a significant influence on the decision to purchase Honda motorcycle spare parts at PT Indako Trading Coy. The results of this study are in line with the research that has been conducted by (Srisusilawati, 2017; Sumiati \& Mujanah, 2018; Yuvita, 2019) who argued that promotion has a significant role in increasing purchasing decisions. In this case, promotion has a significant effect on purchasing decisions because through promotion, consumers will get to know and know the product more. By getting to know and knowing more about the product, consumers will be interested in making a purchase. The higher the promotion intensity, the higher the chance for consumers to make a purchase. Conversely, the lower the promotion intensity, the lower the chance for consumers to make a purchase.

\section{Effect of Product Prices, Service Quality, and Promotion on Purchasing Decisions}

Based on the results of the research, it showed that the variable price, service quality and promotion simultaneously affect the purchasing decision of Honda motorcycle spare parts at PT Indako Trading Coy. This finding is in line with the statement (Petricia \& Syahputra, 2015) that price, service quality, and promotion are several factors that influence consumer decisions. This is because prices that are affordable or cheaper can attract consumers to make purchases, friendly service quality makes consumers feel satisfied in making purchases, by promoting via social media, newspapers using advertisements can make consumers quickly find out their advantages and shortcomings of a product and quickly recognized by consumers can make consumers interested in making a purchase.

\section{Conclusion}

Based on the results of research and discussion, it can be concluded that price, service quality, and promotion partially have a significant influence on the decision to purchase Honda motorcycle parts at PT Indako Trading Coy. Price, service quality, and promotion simultaneously have a significant effect on the decision to purchase Honda motorcycle spare parts at PT Indako Trading Coy. Based on this, it is recommended that companies pay attention to price, service quality, and promotion variables because these three variables greatly influence purchasing decisions

\section{References}

Abdurrahman, S. (2015). Manajemen Strategi Pemasaran. CV. Pustaka Setia.

Alma, B. (2018). Manajemen Pemasaran \& Pemasaran Jasa. Alfabeta.

Carlos Alberto, G., Myriam, M.-F., I.Viedma-del-Jesús, M., \& Aranda, L. A. (2020). The processing of price during purchase decision making: Are there neural differences among prosocial and non-prosocial consumers? Journal of Cleaner Production, 271, 26-48. https://doi.org/https://doi.org/10.1016/j.jclepro.2020.122648

Chang Li, S. (2013). Exploring the Relationships among Service Quality, Customer Loyalty and Word-OfMouth for Private Higher Education in Taiwan. Asia Pacific Management Review, 18(4), 375-389. https://doi.org/10.6126/APMR.2013.18.4.02

Consuegra, Martin, D., Molina, A., \& Esteban, A. (2007). An integrated model of price, satisfaction and loyalty: An empirical analysis in the service sector. Journal of Product \& Brand Management, 16(7), 459-468. https://doi.org/10.1108/10610420710834913

Cronin., J. J., \& Taylor, S. (1992). Measuring Service Quality - A Reexamination And Extension. Journal of Marketing, 56, 55-68. https://doi.org/10.2307/1252296

Kotler, P., \& Amstrong, G. (2012). Prinsip-prinsip Pemasaran (13th ed.). Erlangga.

Kukar-Kinney, M., M.Ridgwaya, N., \& B.Monroe, K. (2012). The Role of Price in the Behavior and Purchase Decisions of Compulsive Buyers. Journal of Retailing, 88(1), 63-71. https://doi.org/10.1016/j.jretai.2011.02.004

Kurniawan, D. A. (2016). Pengaruh Persepsi Harga, Kualitas Pelayanan dan Citra Terhadap Niat Konsumen untuk Word of Mouth dengan Kepuasan sebagai Variabel Mediasi (Survei pada BPJS di Kabupaten Ponorogo). Al Tijarah, 2(1), 94-118. https://doi.org/10.21111/tijarah.v2i1.665

Margaretha, F. (2012). Analisa Pengaruh Food Quality dan Brand Image Terhadap Keputusan Pembelian Roti Kecil Toko Roti Ganep's di Kota Solo. Jurnal Manajemen Pemasaran, 1(1), 1-6. 
Peter, J. P., \& Olson, J. C. (2013). Perilaku Konsumen dan Strategi Pemasaran. Terjemahan (9th ed.). Salemba Empat.

Petricia, D., \& Syahputra. (2015). Pengaruh Kualitas Produk, Harga, Promosi dan Kualitas Pelayanan terhadap Proses Keputusan Pembelian (Studi pada Konsumen Kopi Progo Bandung). Eproceeding of Management, 2(2), 2117-2124.

Rustam, T. A. (2019). Pengaruh Kualitas Produk, Citra Merk dan Promosi terhadap Keputusan Pembelian Spare part pada Bengkel Aneka Motor Kabupatan Padang Pariaman. Owner (Riset Dan Jurnal Akuntansi), 3(2), 320-328. https://doi.org/10.33395/owner.v3i2.159.

Santosa, A. T. (2019). Pengaruh Kualitas Pelayanan, Kualitas Produk, Store Atmosphere, Dan E-Wom Terhadap Proses Keputusan Pembelian (Survei Terhadap Konsumen Zenbu-House Of Mozaru Paris Van Java, Bandung). Jurnal Manajemen Maranatha, 18(2), 148-158. https://doi.org/10.28932/jmm.v18i2.1613

Srisusilawati, P. (2017). Kajian Komunikasi Pemasaran Terpadu Dalam Mendorong Keputusan Pembelian Jasa Perbankan. Amwaluna: Jurnal Ekonomi Dan Keuangan Syariah, 1(1), 1-18. https://doi.org/10.29313/amwaluna.v1i1.1993

Sugiyono. (2014). Metode Penelitian Pendidikan Pendekatan Kuantitatif, Kualitatif, dan R\&D. Alfabeta.

Sumiati, S., \& Mujanah, S. (2018). Persepsi Kualitas Produk, Persepsi Harga dan Promosi Terhadap Keputusan Pembelian Tas Sophie Paris pada Mahasiswa. AMAR (Andalas Management Review), 2(2), 1-10. https://doi.org/10.25077/amar.2.2.1-10.2018

Sunarto, S. (2015). Pengaruh Kualitas Produk Terhadap Keputusan Pembelian Pada Toko Kerajinan Kulit Kartika Magetan. EQUILIBRIUM: Jurnal Ilmiah Ekonomi Dan Pembelajarannya, 3(2). https://doi.org/10.25273/equilibrium.v3i2.668

Tjiptono, F. (2015). Strategi Pemasaran. Andi Offset.

Yuvita, H. (2019). Pengaruh Brand Image Dan Sales Promotion Terhadap Keputusan Pembelian Melalui Brand Equity (Survei Terhadap Nasabah Bank Bni Syariah Di Kota Palembang). MIX: Jurnal Ilmiah Manajemen, 9(1), 431-440. https://doi.org/10.22441/mix.2019.v9i3.004 